\title{
EFFECT OF VARIOUS DOSES OF POTASSIUM ON RESPONSES OF SOYBEAN (Glycine max L.) GENOTYPES INFESTED WITH WHITEFLY (Bemisia tabaci Genn.)
}

\author{
ZUBAIDAH, S. ${ }^{{ }^{*}}-$ MULYANING, I. L. ${ }^{1}-$ KUSWANTORO, H. ${ }^{2}$ \\ ${ }^{1}$ Biology Education Program, Universitas Negeri Malang, Jl. Semarang No. 5, Malang, \\ Indonesia \\ ${ }^{2}$ Indonesia Legume and Tuber Crops Research Institute, Indonesian Agency for Agricultural \\ Research and Development, Jl. Raya Kendalpayak Km. 8, Malang, Indonesia \\ "Corresponding author \\ e-mail: siti.zubaidah.fmipa@um.ac.id; phone: +62-03-41-551-312
}

(Received $2^{\text {nd }}$ March 2020; accepted $9^{\text {th }}$ Jul 2020)

\begin{abstract}
Soybean may undergo growth disorder due to destructive plant organisms. One of these organisms threatening the productivity of soybean is Bemisia tabaci Genn. This research aims to study the response of soybean lines suffering from $B$. tabaci fertilized with four different doses of potassium $(\mathrm{K}), \mathrm{K} 0=0 \mathrm{~g} / \mathrm{kg}$ soil, $\mathrm{K} 1=0.02789 \mathrm{~g} / \mathrm{kg}$ soil, $\mathrm{K} 2=0.055 \mathrm{~g} / \mathrm{kg}$ soil, $\mathrm{K} 3=0.083 \mathrm{~g} / \mathrm{kg}$ soil. This research used a randomized complete block design with three replications. The genotype difference influenced pod width, pod thickness, number of unfilled pods, number of reproductive nodes, days to flowering, and days to maturity. The variation of dose influenced plant height, pod length, number of unfilled pods, the weight of 50 seeds, and days to maturity. Interaction (genotype x fertilizer) affected many aspects such as plant height, pod length, pod width, pod thickness, number of filled pods, total pods per plant, number of reproductive nodes, seed length, seed weight, and seed thickness, the weight of 50 seeds, days to flowering, and days to maturity. The research result of each genotype showed a different response to every dose.
\end{abstract}

Keywords: agronomy, Bemisia tabaci, fertilizer, maturity, honeydew

\section{Introduction}

Many kinds of plant destruction organisms disturb the growth of the soybean plant. Such organisms can be in the form of pests or weeds. Bemisia tabaci Genn. is one of the pests of soybean cultivation (Castillo et al., 2011; DEFRA, 2015). Plant destruction organisms attack some parts of the plant, such as leaf, stem, or root. B. tabaci is an insect sucking the liquid of leaves and spreads the Cowpea Mild Mottle Virus (CpMMV) (Brito et al., 2012; Putnam, 2016). This particular virus can damage the plant structure. Soybean plant infected by CpMMV undergoes leaves spotting, chlorosis, and malformation (Tavasoli et al., 2009; Salaudeen and Aguguom, 2014). The damage to plant structure influences the physiology and metabolism of the plant. The damage to the soybean leaf structure can change the leaf function and the quality, as well as the productivity of soybean Brito et al. (2012).

The efforts to minimize the CpMMV attack carried by $B$. tabaciGenn. have frequently been conducted. One of the efforts is repairing the plant variety. Nowadays, many soybean lines are resistant to CpMMV (Zubaidah et al., 2010). This effort should be continued by fertilizing so that the quality of the soybean line increases. The dose of fertilizer should be adequately applied to streamline the use of fertilizer and maximize productivity. One of the elements needed by the soybean plant in the significant amount 
is potassium $(\mathrm{K})$ since its role is essential for plant growth (Hopkins, 2004; Sczerba et al., 2009).

Potassium $(\mathrm{K})$ is a macromolecule contained in the soil. The high need for the plant to this element can be fulfilled by applying fertilizer containing $\mathrm{K}$ until this particular element can be used well by the plant. The use of $\mathrm{K}$ influences much to the plant. The role of $\mathrm{K}$ is, for example, increasing enzyme activation, reducing the loss of transpiration water through the set of stomata, increasing the production of ATP, helping assimilate translocation, increasing $\mathrm{N}$ absorption and protein synthesis, assisting in balancing carbohydrate and protein, increasing the efficiency of photosynthesis process (Marschner, 1995; Pettigrew, 2008), increasing the plant length and plant production (Hamouda et al., 2015), repairing the destructed tissue (Zain and Ismael, 2016), increasing the efficiency of the use of water (McKenzie and Pauly, 2013). K also has a role in strengthening the cell wall, and it is involved in the process of sclerenchyma tissue lignification so that it can enhance the plant resistance to a particular disease (Baiea et al., 2015).

The plant uses $\mathrm{K}$ in physiology and metabolism processes. The appropriateness of the use of K dose based on the plant need can streamline the plant's physiology process that will have a positive impact on plant productivity. K determines the resistance, quality, and productivity of the plant by noticing the dose based on the need (Magen, 2008; McKenzie and Pauly, 2013). Plant productivity is in the form of agronomical traits produced. Some agronomical characteristics can be observed such as plant height (Farhad et al., 2010), number of branches, number of total pods per plant, the weight of 50 seeds, number of filled pods, number of unfilled pods, total seeds per plant, the weight of seed per plant, days to flowering, and days to maturity (Magen, 2008; Hamouda et al., 2015), number of reproductive nodes and number of leaves (Baiea et al., 2015). This research was done by using the variation of $\mathrm{K}$ dose for soybean genotype attacked by B. tabaci so that the response to the plant's agronomica traits can be known.

\section{Methodology}

\section{Place and Time of Study}

The research was conducted in Kendalpayak Research Station, Indonesian Legume, and Tuber Crops Research Institute, Malang, Indonesia, in November 2016 until January 2017. The preparation was done by filling the soil into a polybag after the soil was dried, sieved, and mixed with manure. The soil used was Entisol soil type. Four seeds of soybean were planted in every polybag and treated based on the fertilizer dose that had been determined. The plant was grown in an open-air condition. The watering and weed cleaning was done once a week until the soybean plants were harvested. The soybean plant is ready to harvest if the pods become yellow or brownish.

\section{Research Design}

This research used a randomized complete block design with three replications to analyze the response of the soybean genotype attacked by B. tabaci. Soybean genotypes used were UM.4-1, UM.7-2, UM.2-4, UM.7-6, UM.6-2 genotypes, and two check varieties of Gumitir and Wilis. These lines were used as the first factor. The treatments of $\mathrm{K}$ dose were $\mathrm{K} 0=0 \mathrm{~g} / \mathrm{kg}, \mathrm{K} 1=0.0278 \mathrm{~g} / \mathrm{kg}, \mathrm{K} 2=0.0550 \mathrm{~g} / \mathrm{kg}$, and $\mathrm{K} 3=0.0830 \mathrm{~g} / \mathrm{kg}$ was used as the second factor. The $\mathrm{K}$ was from $\mathrm{KCl}$ fertilizer. The basal fertilizing was 
also conducted by using $0.0363 \mathrm{~g}$ of nitrogen $(\mathrm{N}) / \mathrm{kg}$ and $0.0917 \mathrm{~g}$ of phosphate $(\mathrm{P}) / \mathrm{kg}$ in order for the plant can grow optimally. The chemical properties of the soil before the treatments applied are presented in Table 1.

Table 1. Soil chemical properties before treatment were applied

\begin{tabular}{c|c}
\hline Soil chemical properties & Value \\
\hline $\mathrm{N}(\%)$ & 0.08 \\
$\mathrm{P}_{2} \mathrm{O}_{5}(\mathrm{ppm})$ & 188.00 \\
$\mathrm{~K}(\mathrm{Cmol} / \mathrm{kg})$ & 0.26 \\
$\mathrm{pH}$ & 6.70 \\
\hline
\end{tabular}

\section{Data Analysis}

The observation was done to the agronomical traits of soybean plant including plant height, number of branches, pod length, pod width, pod thickness, number of filled pods, number of unfilled pods, number total pods, number of reproductive nodes per plant, seed length, seed width, seed thickness, seed weight per plant, the weight of 50 seeds, days to flowering and days to maturity. The digital screw micrometer was used to measure pod length, pod width, and pod thickness, as well as seed length, seed width, and seed thickness after soybean was harvested. The data were analyzed with ANOVA by using SPSS 7.0 program; if the result showed a significant relationship, the LSD test was then conducted.

\section{Results and Discussion}

Variations of $\mathrm{K}$ fertilizer doses have a different effect on the resistance to the honeydew. The honeydew attack was analyzed, and the results are presented in Figure 1. Figure 1 shows that the K0 dose resulted in the lowest percentage value of the resistance compared to the other doses. This case means that by applying this dose, the soybean became the plant that was most resistant to the honeydew. Honeydew is a secondary metabolite produced by $\mathrm{B}$. tabaci. The resistance of the soybean plant by K0 dose was not significantly different from the K2 dose condition. The other doses, such as $\mathrm{K} 1$ and $\mathrm{K} 3$ doses, resulted in the highest percentage value compared to the other doses; it means that the resistance level was lack (almost close to the slightly resistant category). However, the percentage value resulted was still categorized as resistant. This case shows that the $\mathrm{K}$ dose getting higher does not always affect the soybean plant resistance since it is influenced by the other factors as well.

The different response of soybean lines attacked by $B$. tabaci was indicated by the interaction between the soybean lines and variations of $\mathrm{K}$ dose affecting significantly to such 12 variables as the plant height, pod length, pod width, pod thickness, number of filled pods, total pods per plant, number of reproductive nodes, seed width, seed thickness, the weight of 50 seeds, days to flowering and days to maturity ( $p>0.05$ ).

Agronomical traits of the plant determine the quality and productivity of the plant. The following sixteen aspects were observed to determine the response of the plant to the fertilizer. The different influence was shown in the use of genotype, fertilizer, and interaction of both of them to the agronomical traits observed. The analysis of variance is presented in Table 2 . 


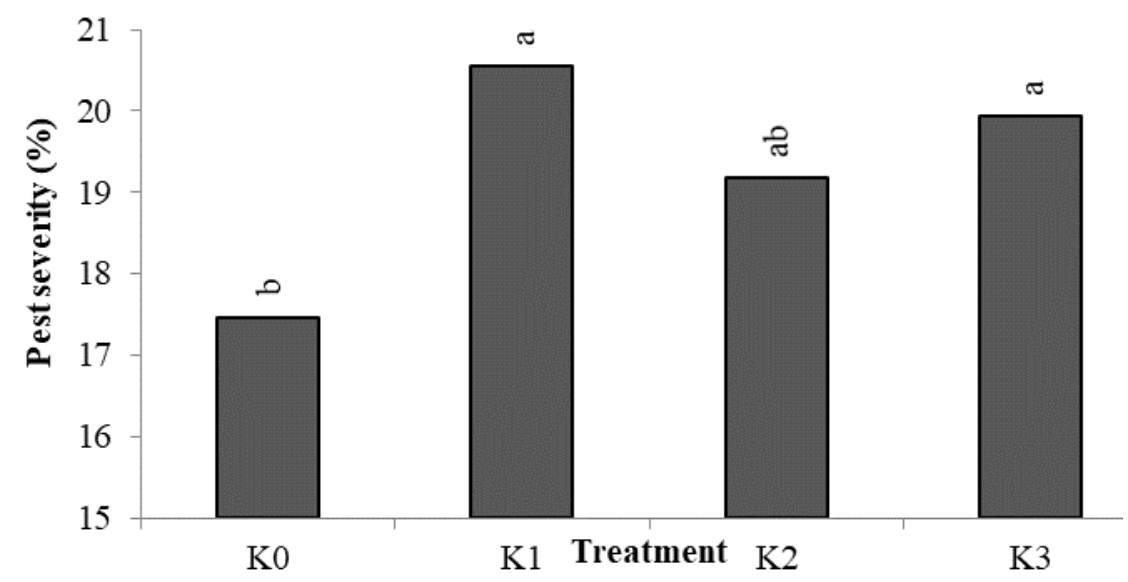

Figure 1. The effect of variations in potassium (K) dose to the percentage of honeydew's resistance

Table 2. Analysis of variance of the agronomy of soybean genotype attacked by B. tabaci

\begin{tabular}{c|c|c|c|c}
\hline & MS genotype & MS fertilizer & MS interaction & MS error \\
\hline Days to flowering & $3.83^{* *}$ & 0.32 & $2.74 * *$ & 0.50 \\
Days to maturity & $166.86^{* *}$ & $218.42^{* *}$ & $149.29 * *$ & 22.59 \\
Plant height & 54.94 & $309.04 * *$ & $177.33 * *$ & 91.25 \\
Number of branches of the main stem & 1.34 & 1.71 & 0.87 & 1.07 \\
Pod length & 0.08 & $0.57 * *$ & $0.94 * *$ & 0.17 \\
Pod width & $1.75 * *$ & $1.97 * *$ & $2.10^{* *}$ & 0.63 \\
Pod thickness & $1.35^{* *}$ & 1.13 & $2.08^{* *}$ & 0.61 \\
Number of filled pods & 180.15 & 18.34 & $239.83 * *$ & 120.19 \\
Number of unfilled pods & $15.48^{* *}$ & $16.42 * *$ & 4.29 & 5.27 \\
Total pods per plant & 254.29 & 12.45 & $206.14 * *$ & 124.43 \\
Number of reproductive nodes & $27.47 * *$ & 1.88 & $14.67 * *$ & 7.76 \\
Seed length & 809.42 & 757.21 & 860.29 & 945.17 \\
Seed width & 0.59 & 0.21 & $0.58 * *$ & 0.33 \\
Seed thickness & 0.44 & 0.07 & $0.48^{* *}$ & 0.29 \\
Weight of 50 seeds & 0.36 & $0.96 * *$ & $0.88^{* *}$ & 0.17 \\
Seed weight per plant & 34.45 & 66.56 & 43.78 & 40.94 \\
\hline
\end{tabular}

UM.2-4 with K3 dose showed the longest days to flowering compared to the other doses. However, the K3 dose that with UM.7-2 and 7-6 lines showed the shortest days to flowering compared to the other doses to these lines. UM.4-1 and 6-2 lines flowered quickly after giving $\mathrm{K} 1$ dose. A variety of Gumitir flowered quickly by giving K0 dose. Meanwhile, a variety of Wilis flowered quickly after giving K2 dose (Figure 2). The speed of days to flowering of a plant is influenced by the plant's metabolism and biochemistry processes. K of a plant increases the plant growth parameter; one of them is flowering initiation (Awon et al., 2012).K can influence the optimum metabolism of the plant so that it can initiate the flowering (Hawkesford et al., 2011). The accuracy of the dose used is the critical factor that should be taken into account. Too much or too little dose can decelerate the flowering process of the plant (Manoj Kumar et al., 2013). 


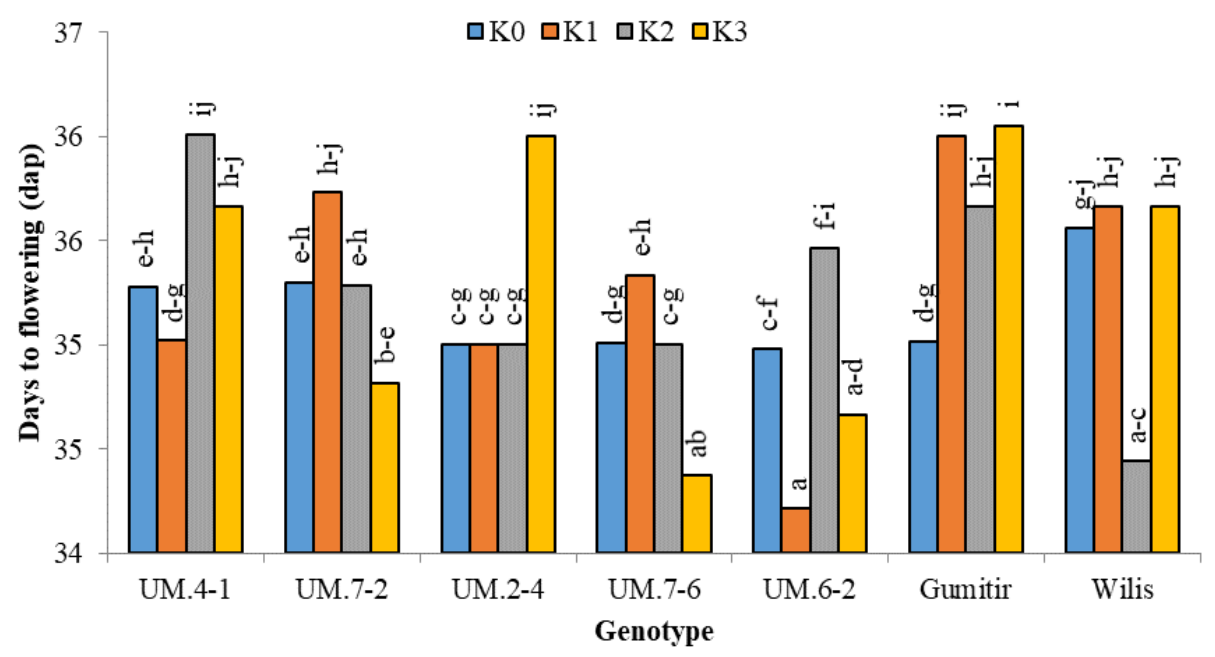

Figure 2. Interaction of genotype $\times$ fertilizer to the days to flowering. Note: dap=day after planting

The UM.7-2 line with K3 dose produced soybean with the quickest days to maturity compared to the other interactions. Days to maturity in the other interactions (besides UM.7-2 line with K3 dose) showed an insignificant difference (Figure 3). The plant growth process determines the speed of days to maturity of the plant. $\mathrm{K}$ determines the optimal metabolism performance to initiate the maturity/crop ripening (Hawkeford et al., 2011). If the plant can grow and develop well, absorb and utilize the nutrition optimally; it can do the metabolism process optimally, and the plant can grow and produce its product optimally. Days to maturity is determined by the character shown by the plant (Manoj Kumar et al., 2013). In soybean plants, if the pods become tawny, it means that the plant is ready to harvest.

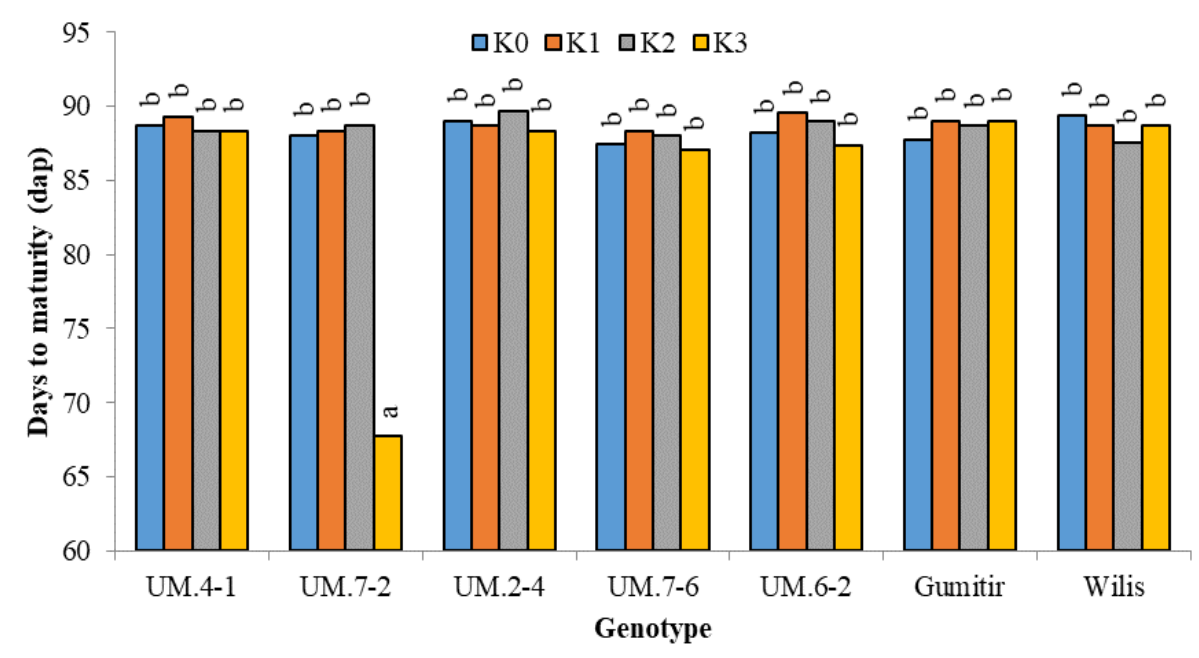

Figure 3. Interaction of genotype $\times$ fertilizer to the days to maturity

The result of the analysis of plant height showed that the UM.6-2 line with K0 dose produced the highest plant, but when it was K3 dose, it produced the shortest plant. On the contrary, the UM.4-1 line produced the highest plant when applied with K3 dose 
and produced the shortest plant when at $\mathrm{K} 0$ dose. Variety of Gumitir showed that the higher the $\mathrm{K}$ dose, the plant growth was getting higher as well. The highest plants were in UM.7-2 and 7-6 lines after they were applied K0 dose. Meanwhile, in the UM.2-4 line and the variety of Wilis, the highest plant was produced at the K3 dose (Figure 4). $\mathrm{K}$ dose and genotype influenced the soybean plant height. The optimum plant height can be reached by giving fertilizer based on the need for soybean genotype. The accuracy in determining the fertilizer dose supports the growth of maximum plant height (Farhat et al., 2010; Yaqoub et al., 2015). A plant needs fertilizer as the nutrition supply; besides, it gets the nutrition from the soil. One of the elements contained in the fertilizer in the treatment is $\mathrm{K}$. $\mathrm{K}$ influences the growth and process as well as the metabolism of the plant (Marschner, 1995), including the increase of fission and cell lengthening (Pal et al., 2016). The plant that is growing with an optimum height is one of the direct effects of giving K (Manal et al., 2016). This case was caused by the fulfillment of nutrition needed by the plant by absorbing it from the soil (Xiang et al., 2012). The research results showed that $\mathrm{K} 0$ and $\mathrm{K} 3$ doses have contributed to influencing the soybean plant height in any genotypes and varieties used. Thereby, we can know that both doses were fitting to the need of some soybean genotypes in initiating the growth of plant height.

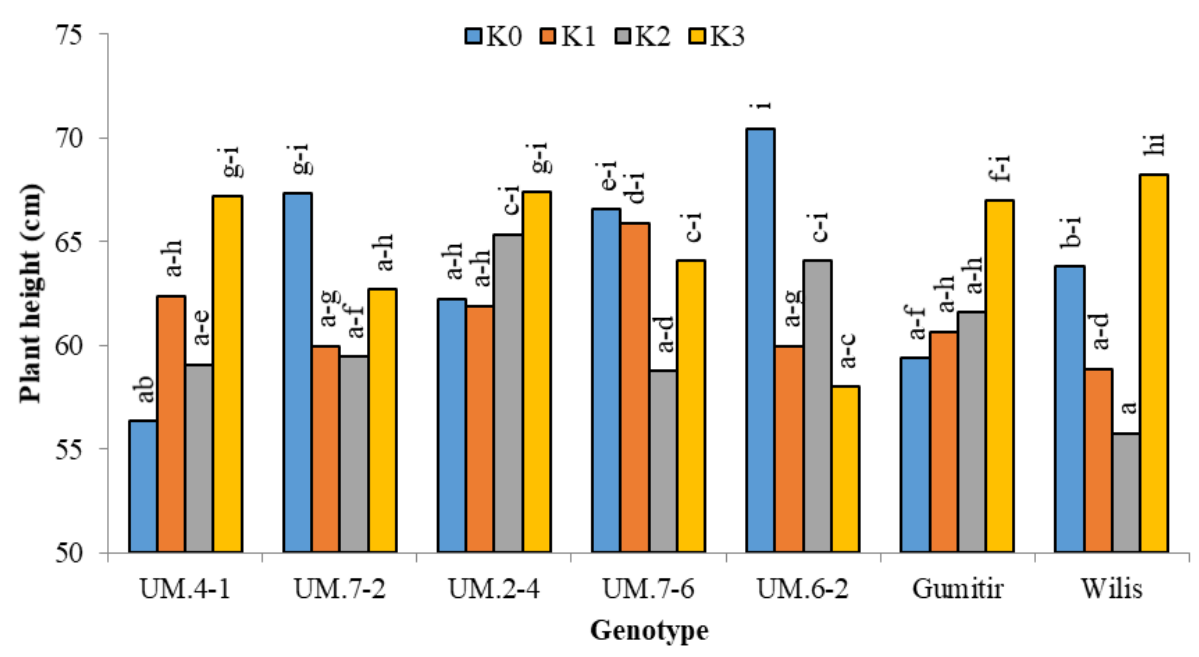

Figure 4. Interaction of genotype $\times$ fertilizer to plant height

The UM.2-4 line that was applied K1 dose produced soybean with the highest number of reproductive nodes compared to several reproductive nodes resulted from giving the other doses. Giving K1 dose to the UM.7-2 line also resulted in the highest number of reproductive nodes. However, Gumitir with K1 dose resulted in the smallest number of reproductive nodes instead since the highest number of reproductive nodes of this variety was produced in UM.4-1. Another dose like K0 on the UM.6-2 line and the variety of Wilis produced the most significant number of reproductive nodes. Meanwhile, if the K0 dose with UM.7-2, 2-4, and 7-6 lines, they produced the smallest number of reproductive nodes (Figure 5). A number of reproductive nodes of a particular plant are closely related to the plant height. Plant height has more areas that can initiate the growth of reproductive nodes rather than the short plant. Thereby, it can be said that higher the plant, the number of reproductive nodes produced will be higher 
as well (Sutrisno and Kuswantoro, 2016).In producing an optimum and high plant, a plant needs sufficient nutrition to facilitate the metabolism process and the growth of the plant. The same thing should be done in forming the reproductive nodes of the plant as well. Giving the right dose of $\mathrm{K}$ is related to the nutrition absorption process needed by the plant (Beg and Ahmad, 2012) so that it can support the optimum growth of the reproductive nodes. The fulfillment of $\mathrm{K}$ and nutrition required to do the metabolism process can result in the character related to plant productivity.

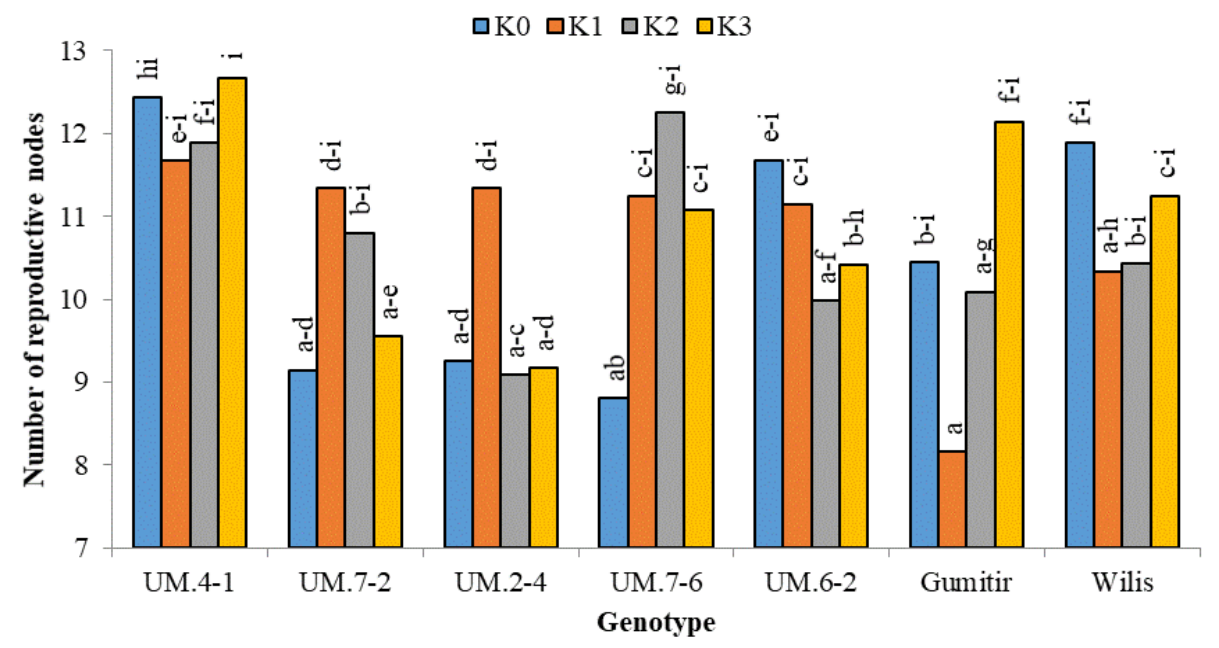

Figure 5. Interaction of genotype $\times$ fertilizer to a number of reproductive nodes

Figure 6 shows that the UM.2-4 line with K1 dose produced the highest total pods compared to the other treatments. A variety of Gumitir with $\mathrm{K} 1$ dose resulted in the smallest number of total pods per plant since the highest number of the total pods had resulted from the K3 dose. In the UM.6-2 line, K0 dose could produce the highest number of total pods per plant, and this condition was similar to the variety of Wilis and UM.4-1line. However, UM.7-2 and 7-6 lines with K0 dose produced the smallest total pods instead. Figure 4 shows that UM.2-4 lines with K1 dose produced the highest total pods compared to the other doses.

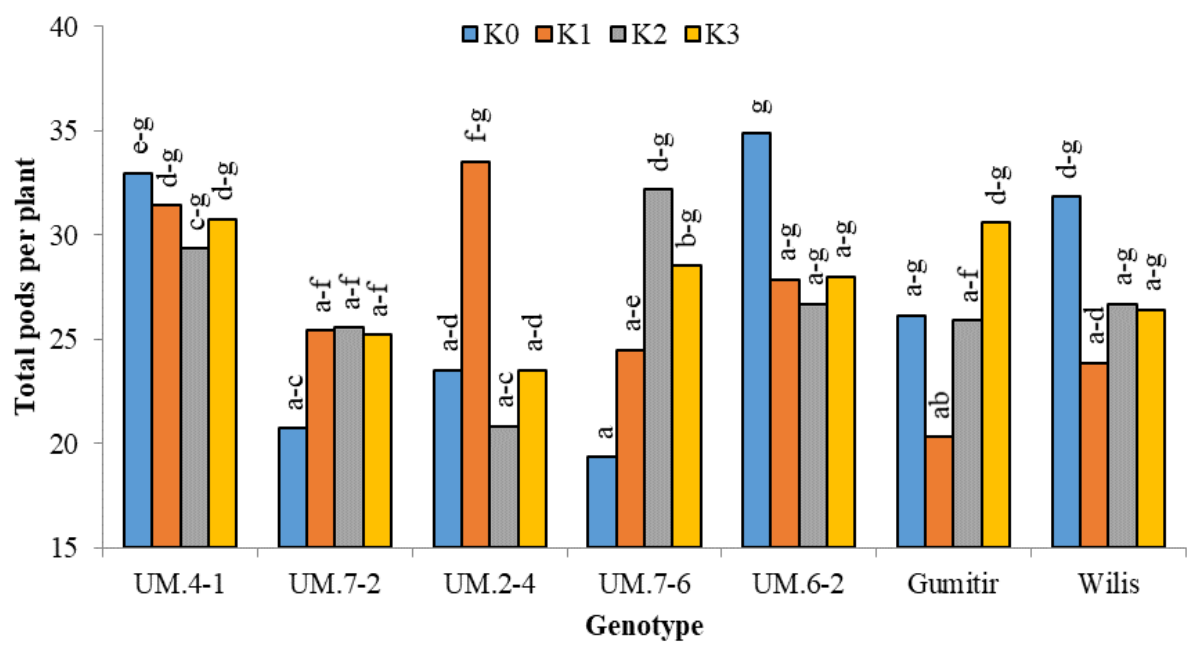

Figure 6. Interaction of genotype $\times$ fertilizer total pods per plant 
Meanwhile, in the variety of Gumitir, K1 dose produced the lowest total pods per plant since the highest total was resulted after applying K3 dose. In the UM.6-2 line, K0 produced the biggest number of total pods per plant, and it was similar to the variety of Wilis and UM.4-1 lines. UM.7-2 and 7-6 with K0 dose produced the smallest total pods. $\mathrm{K} 3$ dose resulted in the biggest total pods only in UM.7-6 line (Figure 6). The total pods per plant are correlated to the number of reproductive nodes of a certain plant (Chakma et al., 2015). A large number of reproductive nodes of a certain plant can maximize the growth of pods of soybean plants. The pod is the product of assimilating the storage of the photosynthesis process. Total pods per plant are influenced by the maximum growth and metabolism of the plant. The optimum growth is realized in forming the pods produced by the plant (Xiang et al., 2012).In the growth process, the soybean plant needs nutrition, and it can get the nutrition from the soil or the fertilizer. Total pods will increase in the plant with $\mathrm{K}$ with the dose matched with the need for the plant (Chauhan et al., 2013). The appropriateness of $\mathrm{K}$ dose is related to the efficiency of its use in the metabolism and biochemistry processed in the plant. The dose that is needed in the various genotypes is based on the need of each soybean genotype.

K0 on to UM.6-2 line and the variety of Wilis, and these lines had the biggest number of filled pods compared to other doses. Meanwhile, UM.7-2 and 7-6 lines had the smallest number of filled pods if they were applied with $\mathrm{K} 0$ dose. Both lines resulted in the highest number of filled pods after giving the K2 dose. However, K2 dose caused the lowest number of filled pods in the UM.4-1 line. Meanwhile, UM.2-4 line with $\mathrm{K} 1$ had the highest number of filled pods compared to the other dose variations. This case contrasted with the variety of Gumitir with the lowest number of filled pods if applied with a K1 dose (Figure 7). A number of filled pods produced showed the plant productivity. Some pods filled seed (filled pod) and unfilled seed (unfilled pod). Soybean plant will be more productive if the number of filled pods is more than the number of unfilled pods. The effectiveness of photosynthesis and assimilate translocation processes in the plant influences number of filled pods (Liesche, 2016). The optimum process is supported by the maximum absorption of nutrition done by the plant (Chakma et al., 2015). $\mathrm{K}$ is one of the nutrition needed by the plant. The fulfillment of $\mathrm{K}$ within the plant can maximize the assimilate translocation process so that there are many filled pods produced. $\mathrm{K}$ as the fertilizer for a plant can increase plant productivity in creating the filled pods (Hussain et al., 2011).

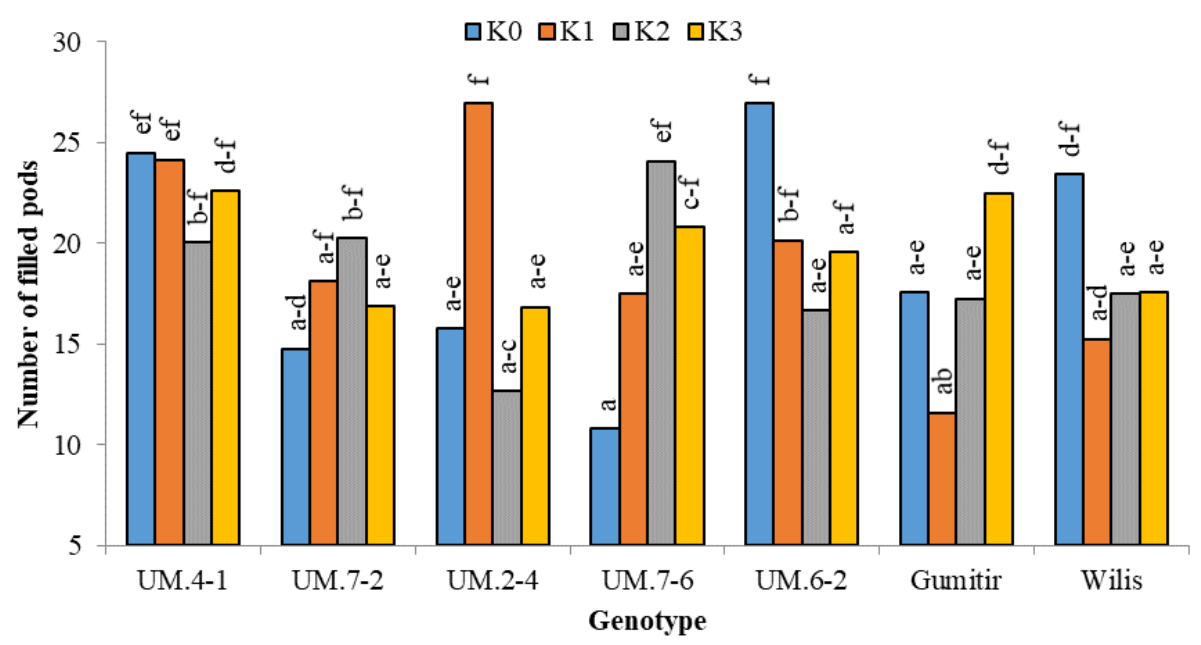

Figure 7. Interaction of genotype $\times$ fertilizer to number of filled pods 
UM.7-6, 4-1, and 2-4 lines that were applied with K1 dose produced the longest soybean pod. However, K1 dose produced the shortest soybean pod on Gumitir and Wilis. In the UM.7-2 line, K0 dose produced the longest pod compared to the other doses. However, this particular dose produced the shortest pod in UM.7-6 and 6-2 lines (Figure 8). The soybean pod produced is one of the plant productivities. Productivity is the result of optimum growth since the need for nutrition can be well fulfilled. The optimum absorption of $\mathrm{K}$ supports the growth of the soybean plant so that it can result in the intended productivity (Abbasi et al., 2014). Seed size filled within the pod influences the pod length. This case is closely related to the process of pod filling, forming the filled pod, which is assimilating the translocation process. $\mathrm{K}$ helps to optimize the plant assimilate translocation.

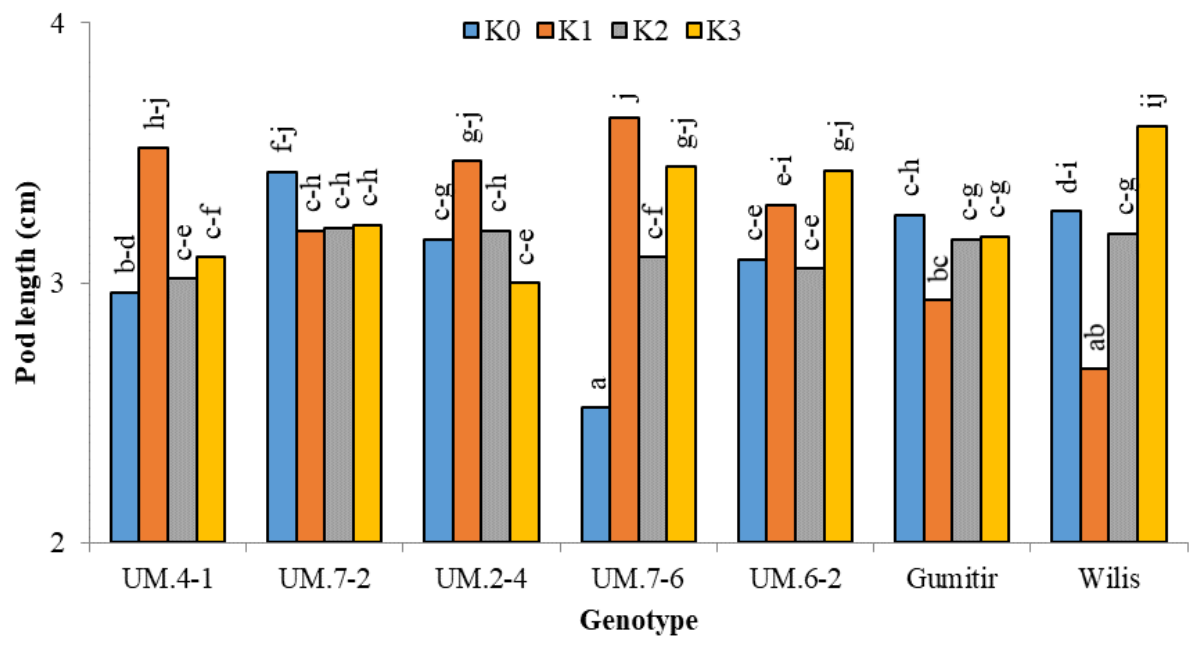

Figure 8. Interaction of genotype $\times$ fertilizer to pod length

The results showed that in UM.7-6 and 7-2 lines, K0 dose produced the widest soybean pod compared to the other doses. Meanwhile, in the variety of Gumitir, the widest pod was produced after givingK3dose. It was different from the UM.6-2 line, which produced the widest pod after giving $\mathrm{K} 0$ and $\mathrm{K} 3$ doses. In the other lines, like UM.4-1, 2-4, and variety of Wilis, the difference of pod width resulted did not show a significant difference (Figure 9). The soybean plant productivity, as indicated by the pod width, produced as well. The optimum growth is fully supported by the availability of nutrition needed in metabolism and photosynthesis processed. The proper $\mathrm{K}$ dose can optimize soybean plant growth (Chen et al., 2007). It was the same with the length and width of soybean pod; they were influenced by the seed size filled within the pod as well. Thereby, the optimum assimilate translocation process truly determines the pod produced with the maximum width. This process can be maximized by fulfilling the need for $\mathrm{K}$ in the plant, based on the need of each genotype.

The less the K dose, the pod produced would be thicker in the UM.2-4 line. UM.7-2 line and variety of Wilis with $\mathrm{K} 0$ dose also produced the thickest pod. However, in UM.4-1, 6-2, and variety of Gumitir, the thickest pod resulted from K3 dose. The lowest dose resulted in thin pods like those in UM.4-1, 7-6, and 6-2 lines. K1 dose produced the thickest pod in the UM.7-6line. However, this dose produced the thinnest pod in UM.7-2line, the variety of Gumitir and Wilis (Figure 10). The thickness of the pod 
produced is correlated to the seed-filled within the pod. The seed quality is obtained from the effectiveness of assimilating translocation from the photosynthesis result by fulfilling the $\mathrm{K}$ dose needed by the plant. The photosynthesis process's effectiveness supports the effectiveness of assimilating translocation influencing plant productivity (Yooyen et al., 2015).

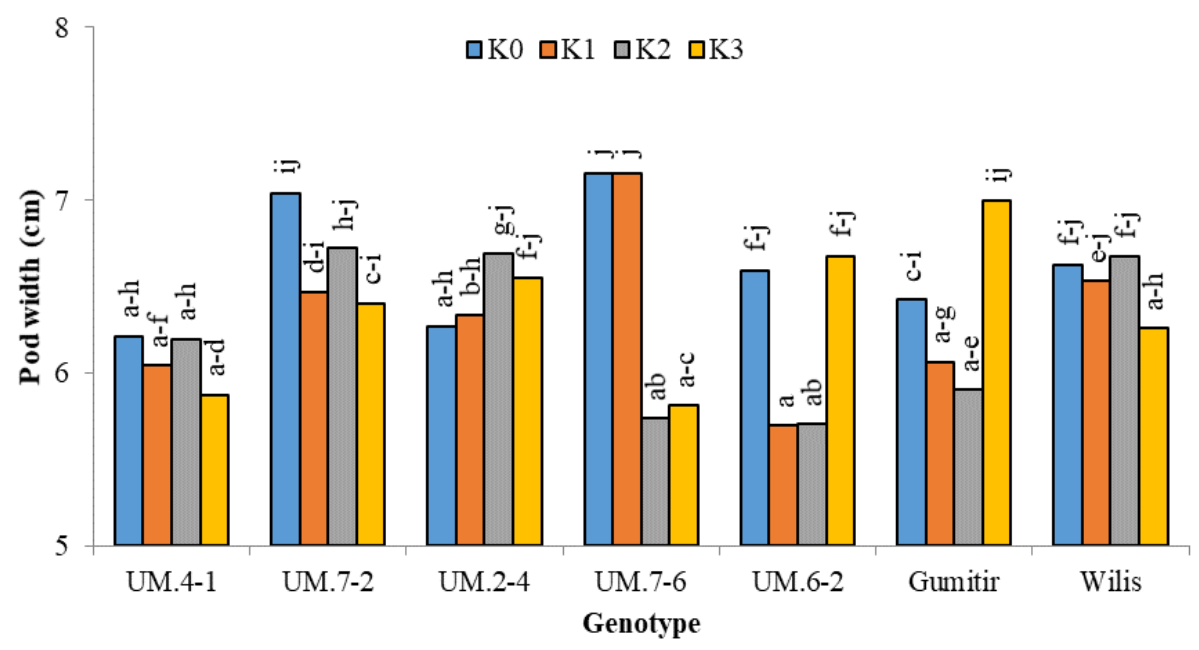

Figure 9. Interaction of genotype $x$ fertilizer to pod width

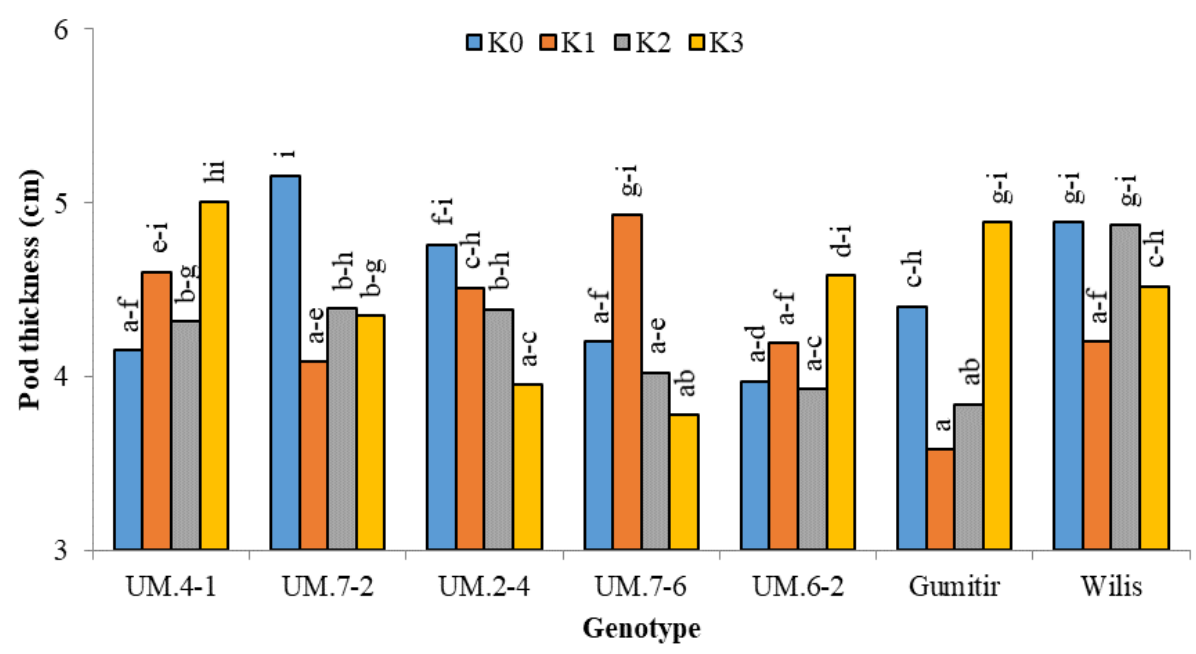

Figure 10. Interaction of genotype $\times$ fertilizer to pod thickness

The higher the K dose, the seed produced in the UM.2-4 line would be wider as well. K3 dose produced the widest seed in the variety of Gumitir. Meanwhile, in UM.4-1, 76, and 6-2 lines, the widest seed was produced after givingK1dose. Besides, the other doses like $\mathrm{K} 0$ dose produced the widest seed only in the variety of Wilis (Figure 11). The seed width influences plant quality and productivity. The seed is produced by the assimilate translocation as the result of photosynthesis (Ayub et al., 2012). The higher the dose, it will be in line with the productivity resulted (Chakma et al., 2015). Some factors influence the production of seed as the result of plant productivity; one of them is the use of fertilizer. Giving the various doses of $\mathrm{K}$ to the plant can initiate the forming 
of seed optimally (Khan et al., 2007; Hosinkhani et al., 2013). The optimum seed is indicated by the thick and wide seed to maximize the plant product and show the effectiveness of the plant productivity.

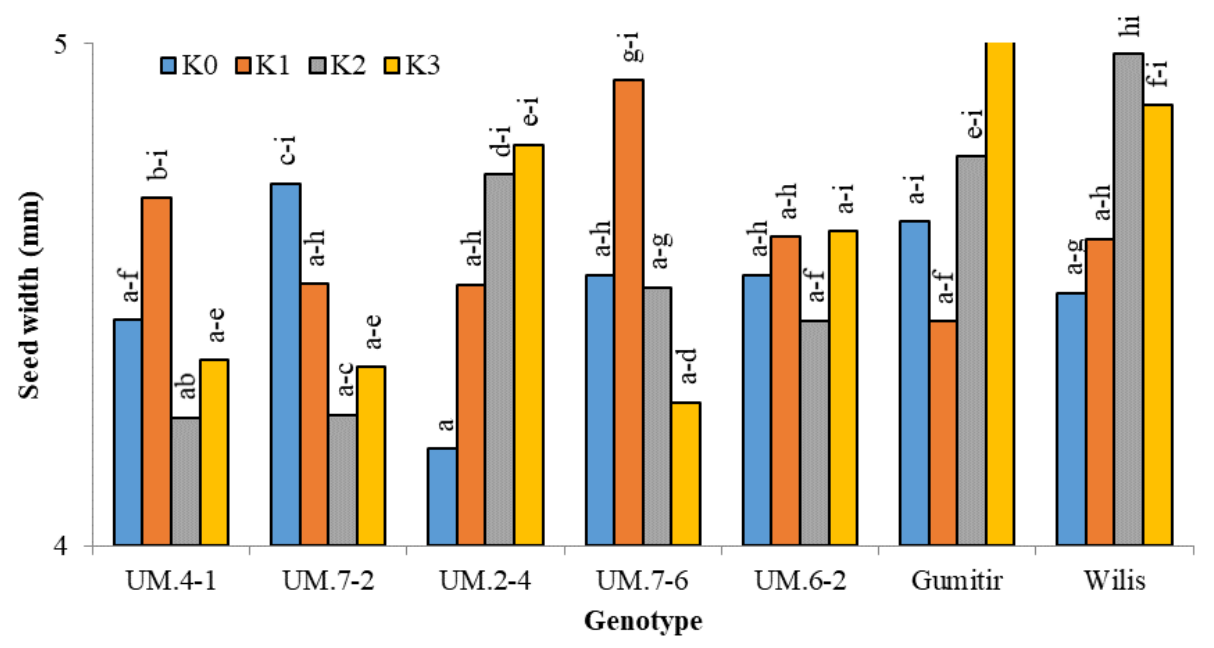

Figure 11. Interaction of genotype $\times$ fertilizer to the seed width

The UM.2-4 line showed that the higher the $\mathrm{K}$ dose, the seed produced would be thicker. UM.6-2line and variety of Gumitir with K3 dose produced the thickest soybean. However, UM.7-2line produced the thickest seed after giving K0 dose. Besides, the other doses, like K1 dose, gave optimum results in the form of thick seed in UM.4-1 and 7-6 lines while K2 dose was optimum in the variety of Wilis (Figure 12). The thick seed showed optimum plant productivity. The optimum productivity can be reached by considering the $\mathrm{K}$ (Mahadik and Chpde, 2015). The productivity is supported by the increase in photosynthesis and assimilate translocation (photosynthate) to produce the crop. K can increase seed productivity resulted from the soybean plant (Asri and Sonmez, 2010). The dose based on the need for the plant can maximize plant productivity. One of the productivity results is the optimum size of the soybean seed.

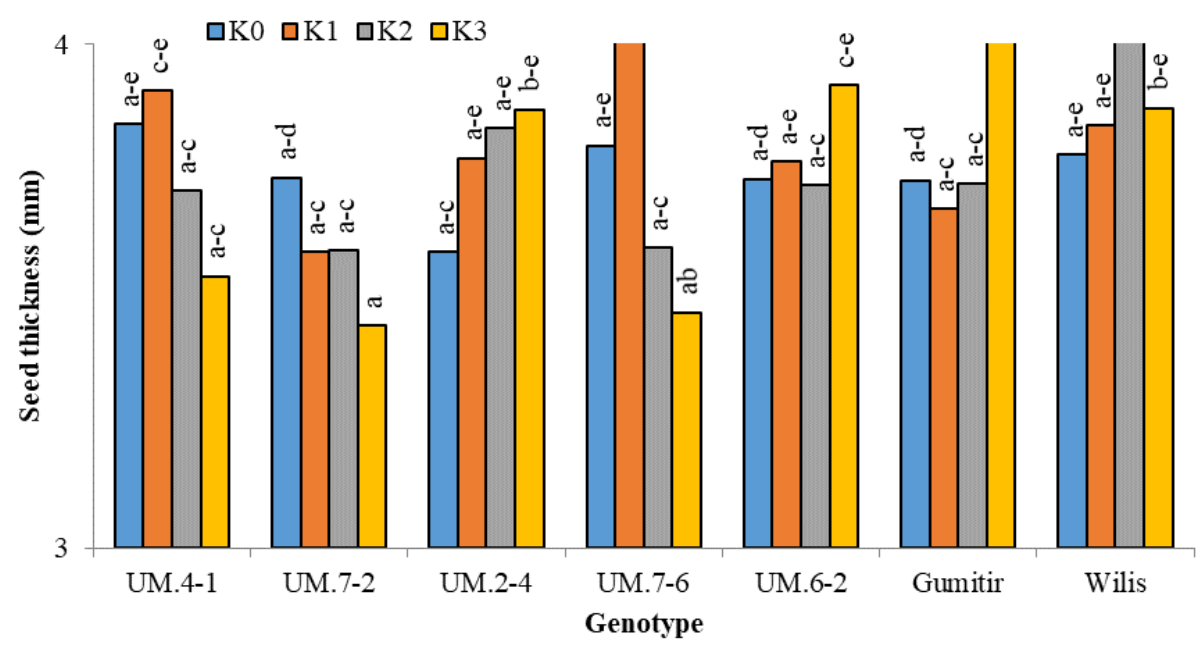

Figure 12. Interaction of genotype $\times$ fertilizer to the seed thickness 
The results showed that a variety of Wilis, UM.7-2, and 6-2 lines with K0 dose produced the soybean with the heaviest weight of 50 seeds. However, the UM.2-4line that was applied with $\mathrm{K} 0$ produced the soybean with the lightest weight of 50 seeds. K2 dose with UM.4-1 line and variety of Gumitir caused the heaviest weight of 50 seeds. However, in a variety of Wilis, K2 dose produced the lightest weight. The UM.2-4 line produced the heaviest weight of 50 seeds when at K1 dose.

On the contrary, when this dose with UM.7-2, 7-6, and 6-2 lines, they produced the lightest seed (Figure 13). The maximum photosynthesis and assimilate translocation processes had produced the thick and wide seed with the highest weight of 50 seeds. If those processed were not optimal, the weight resulted would be low. The photosynthesis and assimilate translocation processes were influenced by $\mathrm{K}$ supporting the growth and metabolism processes (Weerahewa and David, 2015). Fertilizing by using K can increase the assimilate accumulation so that it increases the plant product as well (Calvante et al., 2015). The plant product was in the form of soybean seed. $\mathrm{K}$ is the most effective nutrient in maximizing photosynthesis and photosynthate translocation to increases the weight of the product (Yassen et al., 2010). The increase of plant products can be indicated by the quality of the product resulted. The weight of 50 seeds was influenced by seed thickness and seed width. The thick and wide seed is the result of the intended productivity with high quality. $\mathrm{K}$, in the planting process, influences the quality of the plant product (Dawood et al., 2014; Zhao et al., 2015).

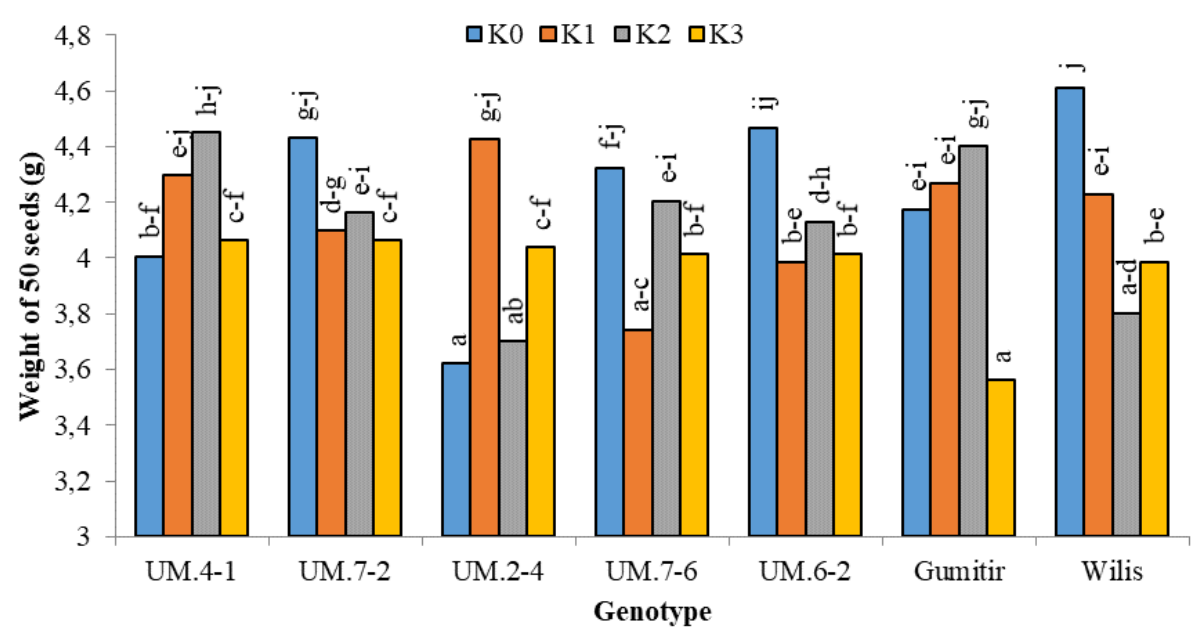

Figure 13. Interaction of genotype $\times$ fertilizer to the weight of 50 seeds

The responses shown were the effect of giving $K$ to the soybean plant attacked by B. tabaci. Fulfilling the need for potassium (K) streamlines its use in influencing the metabolism process (Pettigrew, 2008), and maximizes the plant productivity (Hamouda et al., 2015). The soybean plant productivity was produced from the effectiveness of physiology and biochemistry processes. $\mathrm{K}$ is very significant for and needed by the plant. $\mathrm{K}$ is available within the soil naturally, and it can be provided by giving fertilizer. The plant absorbs the $\mathrm{K}$ within the soil through the transport mechanism of K related to and influences the other mechanisms like water transport (Sczerba et al., 2009) and maintains the cell turgidity that also maintains the leaf form. This case is closely related to the photosynthesis process. The turgid cell can produce the normal shape of the leaf 
so that it can maximize the photosynthesis process (Hopkins, 2004). Photosynthesis produces assimilation that should be translocated from the leaf to the other parts of the plant, such as root, stem, and it will be stored in the food storage. Assimilate translocation can occur optimally if the $\mathrm{K}$ dose is appropriate (Calavante et al., 2015; Al-Shaheen et al., 2016). The optimally assimilate translocation can maximize plant growth, influence plant height, the number of reproductive nodes, influencing total pods so that it is stored in the food storage like seed and pod. The quality of seed and pod is influenced very much by the optimally assimilate translocation. In this research, the assimilate translocation was optimal and able to produce long, wide, and thick pods, also thick and wide seed with some filled pods and total pods per plant as well as the weight of 50 seeds.

All research results of each line showed the different responses of every dose. This case was influenced by the genotype, environment (Thilakarathna and Raizada, 2015), the dose in a planting process (Hellal and Abdelhamdi, 2013), and the soil condition (McKenzie and Pauly, 2013). Therefore, a soil test should be done to optimize the use of potassium dose in every variety and reach the intended product (FAO, 2000). This case is because the appropriateness in determining the dose used will influence productivity (Kuswantoro, 2017).

The relationship among the agronomical traits is known by using correlationregression analysis. The analysis results are presented in Table 3.

Table 3. The Relationship among Agronomical traits

\begin{tabular}{|c|c|c|c|c|c|c|c|c|c|c|c|c|c|c|c|c|}
\hline & DM & $\mathrm{PH}$ & NBMS & PL & PW & PT & NCP & NUP & TPP & NRN & SL & SW & ST & W50 & SWPP & SM \\
\hline DF & 0.038 & 0.242 & 0.089 & -0.274 & 0.109 & -0.059 & -0.119 & 0.116 & -0.098 & 80.034 & 0.018 & 30.107 & 0.135 & 0.157 & $7-0.099$ & -0.097 \\
\hline $\mathrm{DM}$ & & -0.037 & $7-0.428$ & -0.081 & -0.140 & -0.201 & -0.092 & $2-0.071$ & -0.114 & $4-0.019$ & 0.045 & 0.192 & 0.210 & -0.288 & $8-0.006$ & -0.105 \\
\hline $\mathrm{PH}$ & & & 0.077 & 0.138 & 0.267 & 0.147 & -0.040 & -0.275 & -0.078 & $8-0.088$ & 0.218 & 0.235 & 0.069 & -0.022 & 20.106 & -0.145 \\
\hline NBMS & & & & -0.052 & 0.093 & -0.022 & $2-0.030$ & 0.309 & 0.040 & -0.061 & 0.051 & -0.009 & -0.045 & 0.286 & 50.028 & -0.113 \\
\hline PL & & & & & -0.037 & 0.401 & 0.351 & -0.402 & 0.274 & 0.281 & 0.122 & 0.238 & 0.114 & -0.151 & 10.521 & 0.374 \\
\hline PW & & & & & & 0.479 & -0.252 & -0.289 & -0.330 & $0-0.227$ & $0.521^{*}$ & * 0.410 & $0.505^{*}$ & -0.126 & $6-0.037$ & -0.196 \\
\hline $\mathrm{PT}$ & & & & & & & 0.123 & -0.264 & 0.072 & 0.243 & $0.501^{*}$ & * 0.297 & 0.400 & -0.233 & 30.253 & 0.065 \\
\hline NFP & & & & & & & & -0.1910 & $0.973^{* *}$ & "* $0.845^{* *}$ & ${ }^{*}-0.349$ & $9-0.097$ & 0.031 & 0.216 & $50.766^{* *}$ & * 0.435 \\
\hline NUP & & & & & & & & & 0.017 & 0.001 & -0.131 & $1-0.121$ & 0.024 & 0.004 & $4-0.295$ & -0.008 \\
\hline TPP & & & & & & & & & & $0.858^{* *}$ & $*-0.354$ & $4-0.095$ & 0.055 & 0.219 & $90.738^{* *}$ & $* 0.427$ \\
\hline NRN & & & & & & & & & & & -0.180 & 00.006 & 0.138 & 0.051 & $10.675^{* *}$ & ${ }^{*} 0.553^{*}$ \\
\hline SL & & & & & & & & & & & & $0.754^{* *}$ & ${ }^{*} 0.696^{* *}$ & "-0.348 & 80.064 & -0.148 \\
\hline SW & & & & & & & & & & & & & $0.837^{* *}$ & -0.308 & $\begin{array}{ll}80.327\end{array}$ & 0.003 \\
\hline ST & & & & & & & & & & & & & & -0.390 & 00.357 & 0.016 \\
\hline W50 & & & & & & & & & & & & & & & -0.009 & -0.057 \\
\hline SWPP & & & & & & & & & & & & & & & & 0.406 \\
\hline
\end{tabular}

$\mathrm{DF}=$ days to flowering, NUP = number of unfilled pods, $\mathrm{DM}=$ days to maturity, TPP = total pods per plant, $\mathrm{PH}=$ plant height, $\mathrm{NRN}=$ number of reproductive nodes, NBMS $=$ number of branches of the main stem, SL = seed length, $\mathrm{PL}=$ pod length, $\mathrm{SW}=$ seed width, $\mathrm{PW}=$ pod width, $\mathrm{ST}=$ seed thickness, $\mathrm{PT}=$ pod thickness, $\mathrm{W} 50=$ weight of 50 seeds, $\mathrm{NCP}=$ number of filled pods, $\mathrm{SWPP}=$ seed weight per plant, $\mathrm{SM}=$ honeydew

The results showed that there was a significant correlation between some variables. A number of filled pods is related to total pods per plant with a value of 0.973 , meaning that if the number of filled pods is getting higher, total pods per plant will be higher as well. The correlation test score between the number of filled pods and number of 
reproductive nodes per plant was 0.845 ; so there was a significant correlation; if the number of total pods is getting higher, the number of reproductive nodes will increase as well. A large number of reproductive nodes can maximize the pod growth produced in a certain plant (Chakma et al., 2015). This case is influenced by many factors, such as the availability of water and the line of plant type planted (Kuswantoro, 2017).

The number of filled pods is also closely related to seed weight per plant with a score of 0.766. This phenomenon is because the number of filled pods is the form of productivity that resulted from a particular plant. If filled pods produced increase, seed weight per plant would increase as well (Xiang et al., 2012). A large number of filled pods should be continued by the increase in seed and pod size to produce seed weight per plant that significantly increases (Kuswantoro et al., 2014). This phenomenon is because a large amount of filled pods does not always produce seed weight per plant if the seeds produced have a small size.

Total pods per plant were closely related to a number of reproductive nodes with a score of 0.858 . It means that the higher total pods per plant produced, the number of reproductive nodes is getting higher as well. The correlation test between total pods per plant and seed weight per plant revealed a score of 0.738. It showed a significant correlation meaning that the higher the total pods per plant, seed weight per plant is getting higher as well. This phenomenon is because the number and weight are in line due to the positive correlation. The number of reproductive nodes is significantly correlated to seed weight per plant with a score of 0.675 , meaning that a higher number of reproductive nodes, seed weight per plant, is getting higher .

The three aspects, such as the number of reproductive nodes, number of total pods per plant, and seed weight per plant, showed a significant correlation. This case is because the reproductive nodes are the first spots of soybean pod revealing (Chakma et al., 2015). Reproductive nodes are commonly found in the stem and main branch (Kuswantoro, 2017). This thing determines a large number of pods per plant produced by soybean plants. The number of reproductive nodes is related to several filled pods produced by the soybean plant (Kuswantoro, 2017). Thereby, it will be able to influence seed weight per plant produced as well.

The results of the correlation test between seed length and seed width, seed length and seed thickness and seed width, and seed thickness were $0.754 ; 0.696$; and 0.837 , respectively. This case means that there was a significant correlation between seed length and seed width, seed length and seed thickness, and seed width and seed thickness. The longer seed produced, the seed will be wider and thicker as well. Seed length, seed width, and seed thickness influence the quality and productivity resulted (Ayub et al., 2012). The seed is a significant product of the effectiveness of assimilates translocation done by the plant. The seed size is an essential thing in influencing plant productivity. This case is because the seed size determines the seed weight per plant produced directly (Kuswantoro, 2015).

The result of the correlation test also showed a significant correlation between some other variables. Pod width is correlated to seed length and seed thickness with the scores of 0.521 and 0.505 , respectively. Pod thickness is also correlated to seed length, which was 0.501 . This case means that the wider pod, the seed within it will be longer and thicker as well. The long and thick seed produces the wide seed directly so that it is said that seed is optimally produced (Ayub et al., 2012). Thereby, the wide and thick pods are needed to cover the seeds resulted from the soybean plant. 


\section{Conclusions}

Interaction (genotype $\mathrm{x}$ fertilizer) affected many aspects such as plant height, pod length, pod width, pod thickness, number of filled pods, total pods per plant, number of reproductive nodes, seed length, seed weight, and seed thickness, the weight of 50 seeds, days to flowering, and days to maturity. Optimal results were obtained if the dosage is given according to the needs of each soybean genotype. The potassium affected plant height and pod length. The increasing level of potassium leads the pest severity to increase.

Acknowledgments. We gratefully thank Kemenristek BRIN for the Higher Education Basic Research grant funding. We would also like to Bapak Udin (the laboratory staff at UM), Endrik Nur Rohman, Nur Lina Safitri, and Dyah Kusuma Wardhani Syabikhisma Arsy for their valuable contribution to the study.

\section{REFERENCES}

[1] Abbasi, G., Akhtar, J., Anwar-ul-Haq, M., Ali, S., Chen, Z., Malik, M. (2014): Exogenous potassium differentially mitigates salt stress intolerant and sensitive maize hybrids. - Pakistan J. Bot 46: 135-146.

[2] Al-Shaheen, M.R., Soh, A., Ismaaiel, O.H. (2016): Effect of irrigation timing and potassium fertilizing on the some growth characteristics and production for mungbean (Vigna radiata L.). - Inter. J. Sci. Res. Pub. 6(3): 525-528.

[3] Asri, F. O., Sonmez, S. (2010): Reflection of different applications of potassium and iron fertilization on tomato yield and fruit quality in soilless medium. - J. Food, Agric. Environ. 8(3-4): 426-429.

[4] Awon, M., Raza, S., Saleem, M.F., Anjum, S.A., Khaliq, T., Wahid, M.A. (2012): Foliar application of potassium under water deficit conditions improved the growth and yield of wheat (Triticum aestivum L.). - J. Animal Plant Sci.22: 431-437.

[5] Ayub, M., Nadeem, M., Naeem, M., Tahir, M., Tariq, M., Ahmad, W. (2012): Effect of different levels of $\mathrm{p}$ and $\mathrm{k}$ on growth, forage yield and quality of cluster bean (Cyamopsistetra gonolobus L.). - J. Animal Plant Sci. 22: 479-483.

[6] Baiea, M., El-Sharony, T.F., El-Moneim, E. A. (2015): Effect of different forms of potassium on growth, yield, and fruit quality of Mango cv. Hindi. - Inter. J. ChemTech Res. 8(4): 1582-1587.

[7] Beg, M.Z., Ahmad, S.B. (2012): Effect of potassium on moong bean. - Indian J.L. Sci 1(2): 109-114.

[8] Brito, M., Rodriguez, T.F., Garrido, M.J., Majias, A., Romano, M., Marys, E. (2012): First report of cowpea mild mottle carlavirus on yardlong bean (Vigna unguiculata subsp. Sesquipedalis) in Venezuela. - Viruses 4(1): 3804-3811.

[9] Castillo, J.N., Olivé, E.F., Campos, S.S. (2011): Emerging virus diseases transmitted by whiteflies. - Annual Review of Phytopathology 49: 1-576.

[10] Cavalcante, V.S., de Mello Prado, R., de Almeida, H.J., Cruz, F.J.R., dos Santos, D.M.M. (2015): Gaseous exchanges, growth and foliar anatomy of sugarcane plants grown in potassium (K) deprived nutrient solution. - Australian J. Crop Sci. 9(7): 577-584.

[11] Chakma, M., Ali, M.S., Khaliq, Q.A., Rahaman, M.A., Talukdar, M. (2015): The effect of chemical fertilizers on the yield performance of soybean genotypes. - Bangladesh Res. Pub. J. 11(3): 187-192.

[12] Chauhan, S., Titov, A., Tomar, D.S. (2013): Effect of potassium, sulphur and zinc on growth, yield and oil content in soybean (Glycine max.L) in vertisols of central India. Indian J. App. Res. 3(6): 489-491. 
[13] Chen, Z., Zhou, M., Newman, I.A., Mendham, N.J., Zhang, G., Shabala, S. (2007): Potassium and sodium relations in salinised barley tissues as a basis of differential salt tolerance. - Funct. Plant Biol. 34: 150-162.

[14] Dawood, M. G., Magdi, T., Abdel, H., Schmidhalter, U. (2014): Potassium fertilizer enhances the salt-tolerance of common bean (Phaseolus vulgaris L.). - J. Hort. Sci. Biotechnol. 89(2): 185-192.

[15] Department for Environment Food and Rural Affairs (DEFRA) (2015): Bemisia tabaciThe Tobacco Whitefly. - Availableat: http://www.defra.gov.uk/planth/ph/htm, accessed on $13^{\text {th }}$ of June 2016

[16] Farhad, I.S.M., Islam, M.N., Hoque, S., Bhuiyan, M. (2010): Role of potassium and sulphur on the growth, yield, and oil content of soybean (Glycine max L.). - Academic J. Plant Sci. 3(2): 99-103.

[17] Food and Agricultural Organization (FAO) of The United Nations and International Fertilizer Industry Association (IFA). (2000): Fertilizers and their use: a pocket guide for extension officers. $-4^{\text {th }}$ ed. FAO and IFA; Rome.

[18] Hamouda, H.A., El-Dahshouri, M.F., Manal, F.M., Thalooth, A.T. (2015): Growth, yield, and nutrient status of wheat plants as affected by potassium and iron foliar. - Inter. J. ChemTech Res. 8(4):1473-1481.

[19] Hashi, U.S., Karim, A., Saikat, H.M., Islam, R., Islam, M.A. (2015): Effect of salinity and potassium levels on different morpho-physiological characters of two soybeans (Glycine max L.) genotypes. - J Rice Res 3(3): 1-5.

[20] Hawkesford, M., Horst, W. J., Kichey, T., Lambers, H., Schjoerring, J., Müller, I.S., White, P. (2011): Functions of macronutrients: potassium. - In: Marschner, H. (ed.) Marschner's mineral nutrition of higher plants. Elsevier, pp. 135-189.

[21] Hellal, F.A., Abdelhamid, M.T. (2013): Nutrient management practices for enhancing soybean (Glycine max L.) production. - Acta Biol. Colomb. 18(2): 239-250.

[22] Hopkins, W.G. (2004): Introduction to plant physiology. $-3^{\text {rd }}$ ed. Huner NPA, John Wiley and Sons; USA.

[23] Hosinkhani, M.A., Kordlaghari, K.P., Balouchi, H.R. (2013): Effects of potassium and iron nutrient elements on the quantity yield of shariar wheat cultivar in Boyerahmad region. - Annals of Biol. Res.4: 56-60.

[24] Hussain, F., Malik, A.U., Haji, M.A., Malghani, A.L. (2011): Growth and yield response of two cultivars of mungbean (Vigna radiata) to different potassium levels. - J. of Animal Plant Sci.21: 622-625.

[25] Khan, R., Gurmani, A.R., Gurmani, A.H., Zia, M.S. (2007): Effect of potassium application on crop yields under wheat-rice system. - Sarhad J. Agric.23: 277-279.

[26] Kuswantoro, H., Zubaidah, S., Sulisetijono, S. (2014): Decreasing grain size caused declining grain yield of CpMMV-resistant soybean lines grown in ultisols. - J. Biol. Sci. 14(8): 508-514.

[27] Kuswantoro, H. (2015): Increasing grain size improves grain yield of acid-adaptive soybean lines in optimal soil condition. - J. Plant Sci. 10(3): 79-89.

[28] Kuswantoro, H. (2017): Genetic variability and heritability of acid-adaptive soybean promising lines. - Biodiversitas 18(1): 378-382.

[29] Liesche, J. (2015): How regulation of phloem transport could link potassium fertilization to increased growth. - Tree Physiology 36: 1-5.

[30] Magen, H. (2008): Balanced crop nutrition: fertilizing for crop and food quality. - Turk J. Agric. For. 32: 183-193.

[31] Mahadik, M.K., Chopde, N. (2015): Influence of nitrogen and potassium on growth and yield of gladiolus corms. - Plant Archives 15(1): 193-196.

[32] Manal, F.M., Thalooth, A.T., Amal, G.A. (2016): Performance of wheat plants in sandy soil as affected by foliar spray of potassium and zinc and their combination. - Inter. J. ChemTech Res. 9(7): 715-725. 
[33] Manoj Kumar, M.L.M., Kumar, S., Maji, S., Kumar, D. (2013): Effect of nitrogen, phosphorus, and potassium fertilizers on the growth, yield, and quality of tomato var. Azad T-6. - The Asian J. Hort. 8(2): 616-619.

[34] Marschner, H. (1995): Mineral Nutrition of Higher Plants. - $2^{\text {nd }}$ ed. Academic Press; San Diego.

[35] McKenzie, R.H., Pauly, D. (2013): Potassium fertilizer application in crop production. Practical Information for Alberta's Agriculture Industry 542(9), Available at: http://www.agriculture.alberta.ca, accessed on $12^{\text {th }}$ of June 2016.

[36] Pal, J., Adhikari, R.S., Negi, J.S. (2016): Effect of nitrogen, phosphorus, and potassium on growth and green herb yield of Thymus serphyllum. - Int. J. Curr. Microbiol. App. Sci. 5(1): 406-410.

[37] Pettigrew, W.T. (2008): Potassium influences on yield and quality production for maize, wheat, soybean, and cotton. - Physiologia Plantarum 133: 670-681.

[38] Putnam, A.H. (2016): Detection of Bemisia tabaci (Gennadius) 'Q' biotype in southern Florida. - Florida Department of Agriculture and Consumer Services; Florida.

[39] Salaudeen, M.T., Aguguom, A. (2014): Identification of some cowpea accessions tolerant to cowpea mild mottle virus. - Inter. J. Sci. Nat. 5(2): 261-267.

[40] Sczerba, M.W., Britto, D.T., Kronzucker, H.J. (2009): K ${ }^{+}$transport in plants: physiology and molecular biology. - J. Plant Physiol. 166(1): 447-466.

[41] Sutrisno, S., Kuswantoro, H. (2016): Cowpea mild mottle virus (CpMMV) infection and its effect to performance of South Korean soybean varieties. - Biodiversitas 17(1): 129133.

[42] Tavasoli, M., Shahraeen, N., Ghorbani, S.H. (2009): Serological and RT-PCR detection of cowpea mild mottle carlavirus infecting soybean. - J. Gener. Mol Vir. 1(1): 7-11.

[43] Thilakarathna, M.S., Raizada, M.N. (2015): A Review of nutrient management studies involving finger millet in the semi-arid tropics of Asia and Africa. - Agronomy 5: 262290.

[44] Weerahewa, D., David, D. (2015): Effect of silicon and potassium on tomato anthracnose and on the postharvest quality of tomato fruit (Lycopersicon esculentum Mill.). - J. Natn. Sci. Found. of Sri Lanka 43(3): 273-280.

[45] Xiang, D.B., Yong, T.W., Yang, W.Y., Wan, Y., Gong, W.Z., Cui, L., Lei, T. (2012): Effect of phosphorus and potassium nutrition on growth and yield of soybean in relay strip intercropping system. - Scientific Research and Essays 7(3): 342-351.

[46] Yagoub, S.O., Salam, A.S.K., Hassan, M.M., Hassan, M.A. (2015): Effects of organic and mineral fertilizers on growth and yield of soybean (Glycine max L. Merril). - Inter. J. Agron. Agric. Res. 7(1): 45-52.

[47] Yassen, A.A., Habib, A.M., Sahar, M.Z., Khaled, S.M. (2010): Effect of different sources of potassium fertilizers on growth yield and chemical composition of Calendula officinalis. - J. Amer Sci. 6(12): 1044-1048.

[48] Yooyen, J., Wijitkosum, S., Sriburi, T. (2015): Increasing yield of soybean by adding biochar. - J. Environ. Res. Develop. 9(04): 1066-1074.

[49] Zain, N.A.M., Ismail, M.R. (2016): Effects of potassium rates and types on growth, leaf gas exchange., \& biochemical changes in rice (Oryza sativa). - Agric. Water Manag. 164(1): 83-90.

[50] Zhao, X., Du, Q., Zhao, Y., Wang, H., Li, Y., Wang, X., Yu, H. (2015): Effects of different potassium stress on leaf photosynthesis and chlorophyll fluorescence in maize (Zea Mays L.) at seedling stage. - Agric. Sci. 7: 44-53.

[51] Zubaidah, S., Corebima, A.D., Kuswantoro, H. (2010): Pembentukan varietas unggul kedelai tahan CpMMV (cowpea mild mottle virus) umur $<80$ hari berdaya hasil tinggi (potensi hasil > $2.5 \mathrm{t} / \mathrm{ha}$ ) dan kehilanganhasil< 10\%. - Ringkasan Eksekutif Hasil-hasil Penelitian Tahun 2010.

Available at: http://www.litbang.pertanian.go.id/ks/one/636/file/297-298PEMBENTUKAN-VARIET.pdf, accessed on $12^{\text {th }}$ of February 2016. 